\title{
State Building as a Source of Islamic Political Organization ${ }^{1}$
}

\author{
Colin J. Beck ${ }^{2}$
}

\begin{abstract}
Previous research on political Islam in the Middle East and North Africa has been limited in providing a generalizable theory of its origins and systematically account for the cross-national variation in the prevalence of Islamic movements. Following a state-centered approach, this study argues that state-building activities are a primary origin of Islamic movements. Regimes adopt religious symbolism and functions that legitimate the role of Islam in the public sphere. State incorporation of religion thus creates Islam as a frame for political action, with increased access to mobilizing resources and better able to withstand repression and political exclusion. To provide an explicit and systematic test of cross-national variation, data on 170 political and militant organizations across the region are analyzed. Results indicate that state incorporation of religion is a crucial factor in the religiosity of movement organizations. Mixed effects of political exclusion and repression are found. No support is found for theories of economic grievances or foreign influence as causes of Islamic mobilization. In sum, analysis suggests that a state-centered perspective is the most fitting account of political Islam.
\end{abstract}

KEY WORDS: Islam; Middle East; political sociology; social movements; state building; symbols.

\section{INTRODUCTION}

In the past 3 decades, Islam seems to have become the most prevalent mobilizing ideology for movements in the Middle East and North Africa, particularly for those who oppose established regimes. Islamic

1 The author acknowledges the significant contributions of John W. Meyer, Doug McAdam, and Albert J. Bergesen. The author also thanks Charles Kurzman, Rebecca L. Sandefur, Morris Zelditch, Jr., and participants of Stanford University's Comparative Education and Political Systems Workshop and Workshop on Collective Action and Social Movements for their insights and comments. A previous version of this article was presented at the American Sociological Association 2006 Annual Meeting in Montreal, Canada.

2 Department of Sociology, Stanford University, 450 Serra Mall, 120-160, Stanford, California 94305; e-mail: cbeck@stanford.edu. 
mobilization, collective action with religiously inspired goals or motivations, almost seems to be the default reaction for Middle Eastern politics. The phenomenon has spawned a wide array of scholarship on the causes and consequences of political Islam. Specifically, this study considers two questions: (1) Why does political action in the Middle East and North Africa take an Islamic form? and (2) Why does the prevalence of Islamic political organization vary from country to country?

Previous perspectives on the origins of political Islam have considered the role of grievances in motivating mobilization, religious movements as reactions to foreign influence and neoimperialism, and how a social movement theory approach can explain the dynamics of Islamic activism. This study, however, relies on a fourth perspective. Following a state-centered institutional approach advocated by Starrett (1998), Nasr (2001), and Moaddel (2002a), I contend that state-building activities vis-à-vis religion are a primary source of variation in political Islam in the contemporary Middle East. Specifically, I argue that the degree to which states incorporate religious symbols and functions in their practice is an origin of Islamic movements. I propose that regimes construct a public role for religion that inadvertently creates Islam as a legitimate frame for political action. State incorporation of religion also allows movements to plausibly claim that Islam is the solution to social problems. Furthermore, regimes channel resources to religious institutions and create a site of mobilization relatively protected from political exclusion and state repression. Thus, regimes open themselves to oppositional religious challenges from below as a consequence of state building.

State-centered research on political Islam has often considered the intensity of Islamic activism (see, e.g., Nasr, 2001). Yet, another effect of state action may lie at the organizational level. Movements centered on Islam become more prevalent than secular organizations due to the wider conditions generated by state building. The modern Middle Eastern state structures the political field of its society, and it is here that a key origin of movement organizations lies. Second, it is also common for research on Islamic activism to be only implicitly concerned with variation. Since recent scholarship has been dominated by case study or comparative case methods (see, e.g., Clark, 2004; Hafez, 2003; Schwedler, 2006; Wickham, 2002), researchers have been unable to systematically test theoretical models of variation in political Islam across the entire region.

To address these issues, I collect and analyze data on 170 Middle Eastern and North African political and militant organizations across the entire region. Using additional data collected on the nation-state level, binary logistic regression is employed to analyze the predictors of organizational religiosity. Results indicate that state incorporation of 
religion is a key origin of political Islam and its variation. Through a synthesis of institutional and state-centered approaches, the contributions of this study to our understanding of political Islam are thus twofold: (1) it considers organizational outcomes of state action; and (2) it provides an explicit empirical test of cross-national variation. Before presenting the analyses, I review previous approaches and discuss the role of state action in the formation of political Islam.

\section{PERSPECTIVES ON THE SOURCES OF ISLAMIC MOBILIZATION}

Previous perspectives on the origins of Islamic mobilization in the Middle East can be broadly sorted into four separate approaches: (1) grievance-based accounts; (2) the role of foreign influence or neoimperialism; (3) social movement theory; and (4) state-centered factors. Although roundly dismissed by social science researchers (see Krueger and Maleckova, 2003; Norris and Inglehart, 2002), grievance explanations consistently appear in policy, the press, and public opinion.

One explanation is that a lack of democracy is a crucial problem (see U.N. Development Program, 2002), and leads to the growth of Islamic fundamentalist movements that challenge autocratic regimes. Others argue that the Islamic world is "antimodern," and religious movements are a rejection of the West's paradigm of human and civil rights (see Barth, 2000; Bendle, 2003) or that there is a "clash of civilizations" (Bergesen, 2008; Etzioni, 2008; Huntington, 1996). However, there is evidence that cultural differences do not extend to political values, and that Islam and democracy are, in fact, compatible (Norris and Inglehart, 2002). Economic conditions, in particular poverty and inequality, also may have a role to play in Islamic mobilization. Yet Krueger and Maleckova (2003) have shown that economic grievances are not a significant root of support for militancy; in fact, those who support religious mobilization are often from higher educational and socioeconomic backgrounds.

Another perspective on the rise of political Islam with a long history is the role of foreign influence-Western powers subject the Middle East to political, economic, and social control and political Islam is a reaction to this neoimperialism (Aburish, 1997; Chomsky, 1983, 2002; Said, 1978). More recently, Pape $(2003,2005)$ argues that militancy is in part a nationalist reaction to foreign occupation. Ayoob (2005) also sees external influences as a necessary cause of Islamic militancy. Foreign support for a regime certainly can be de-legitimating and a motivating factor in the growth of opposition (Snow and Marshall, 1984). However, an illegitimate regime is likely to face more opposition in general. Thus, foreign 
influences may actually be an indicator of a regime's overall political weakness. Given the limitations of these approaches, social scientists have turned to other perspectives for an explanation of Islamic mobilization.

In the wake of September 11, scholars of the Middle East discovered social movement theory and social movement theorists discovered the Middle East. Although social movement approaches to political Islam existed previously (e.g., Kurzman, 1996), they are the basis for much recent scholarship (see, e.g., the many contributors to Wiktorowicz, 2004). Movement research on the modern Middle East has examined mobilizing resources (Wickham, 2002), networks of recruitment (Clark, 2004), framing and ideational processes (Schwedler, 2006; Snow and Byrd, 2007), and the application of new social movements theory to Islam as identity-based contention (Sutton and Vertigans, 2005). Collective action accounts tend to locate the primary causes of political Islam in movement dynamics. Yet the environment in which Islamic movements operate is an important condition (Ayoob, 2005). Thus, another approach to Islamic mobilization has adopted the political process model of movements, which includes conditions of the broader political environment as key factors. For instance, it is a common view that political liberalization in the early 1990s created a new political opportunity for Islamic movements (Hafez, 2003; Schwedler, 2006; Wickham, 2002). However, political opportunity accounts of social movement emergence are debated, and there is no clear answer as to why certain opportunities create mobilization and others do not (Meyer, 2004). Nor can the opportunity for mobilization alone explain why Islam becomes a dominant form of political action, rather than some other ideology. For these questions, a different theoretical perspective may be required.

The final approach to the source of Islamic mobilization has focused on the role of regimes. State-centered explanations of religious mobilization have a long tradition in social science (see, e.g., Swanson, 1967), and commonly view the autonomous power of religion as a crucial problem for regimes engaged in state building and centralization (Eisenstadt, 1999; Mann, 1986; Rokkan, 1975). Religious institutions, in particular, are a latent source of mobilization due to their long history and general legitimacy. For instance, the Catholic Church in Communist Poland provided one source for democratic movements and the growth of civil society as it was an autonomous space protected from the state (Casanova, 1994; Gautier, 1998). Within studies of the Islamic world, the importance of statereligion relations has also been recognized (Arjomand, 1988, 2001; Moaddel, 2002b; Sharabi, 1963). State action is thus a crucial part of the story of Islamic mobilization, as Middle Eastern regimes set the rules of the political game. For example, a state-centered view of the political liberalization of the 1990s recognizes that it was not only an opportunity for 
mobilization, but was also created by regimes to maintain their power and provide avenues for the social control of opposition (Wiktorowicz, 2000).

Essentially, there are two imageries in the state-centered approach to political Islam. In a search of legitimacy and to coopt opposition, statebuilding regimes either (1) regulate or take control of religious practice, which sparks a mass-based reaction (Clark, 2004; Hafez, 2003; Moaddel, 2002a) or (2) the state adopts religious symbols and functions, which inadvertently legitimates future Islamic political action (Nasr, 2001; Starrett, 1998). Although I am more convinced by the latter depiction, both views locate the origins of Islamic mobilization in the actions of regimes. Statecentered accounts also readily lend themselves to theories of cross-national variation in Islamic political organization. I argue that state-building activities, specifically a regime's incorporation of religious function and symbolism, are the primary explanation of variation in Islamic mobilization across the Middle East.

\section{STATE BUILDING AS A SOURCE OF VARIATION}

As independence from Western colonization and the Ottoman Empire swept across the Middle East, newly formed regimes faced the dilemma of consolidating and legitimating their power. While some regimes, like Kemalist Turkey, consciously secularized their nations, most regimes adopted some degree of religious symbolism as a basis of their rule. Even the father of pan-Arabism, Egypt's Nasser, displayed the callus on his forehead (from prostration during prayer) as evidence of his devotion. Furthermore, regimes sought to control the functions of religion, be it in the mosque, the waqf, or the madrasa, "as a facet of the state's drive to establish hegemony over society and expand its powers and controls" (Nasr, 2001:4).

Contemporary Middle Eastern and North African states incorporate religion in a variety of ways. Some states seek formal control over religious authorities, such as in Egypt where the clergy and scholars of AlAzhar put an Islamic face on an otherwise secular regime (Starrett, 1998). Secular regimes seek to control religious education, appointments of clergy in state-sanctioned mosques, and the content of Friday prayer sermons. States also may incorporate or regulate religious endowments and social welfare charities, which have traditionally had an important role in the public sphere (Eisenstadt, 2002). Even a cursory look at national constitutions reveals that, at the very least, most Middle Eastern governments acknowledge Islamic law, Shari'a, as a source or basis of their rule. On the other end of the spectrum, regimes such as Saudi Arabia and 
post-1979 Iran go so far as to maintain religion as part of the political system in both state practice and theology.

State reliance on religion as one aspect of legitimacy thus maintains a place in the public sphere for Islam. However, the attempted incorporation and cooptation of religion has political consequences. Just as European monarchies that forged nations out of their various peoples opened themselves to nationalist challenges from below (Andersen, 1991), Middle Eastern regimes that maintain a public role for religion create an opportunity for oppositional Islamic movements. Specifically, state incorporation of religion creates religious movements through the construction of Islam as a legitimate mobilizing frame for political action. A regime's maintenance of a public role for Islam also allows increased access to mobilizing resources for religious political organizations, and the creation of a site of mobilization that is sheltered from political exclusion and state repression. These subsidiary mechanisms lie, in part, in movement processes and dynamics. However, they are dependent on the conditions of the political and social environment created by state action. Religious political organization is thus a consequence of Islam's state-promoted public role.

One perspective in social movements research is that oppositional movements will use frames of political action that have general resonance among society at large. Social movement theory terms this process "frame alignment," where a movement connects its claims to larger narratives and beliefs to gain legitimacy and support (Snow et al., 1986). Ideologies with an established role in public and political spheres are prime candidates for strategic framing efforts, as they are generally known and often widely legitimate. In the Middle East, state incorporation of religion gives Islam a legitimate public role by:

the creation of the need for religious information, the tendency to look toward religion for certain things, the creation of certain compartments in a conceptual order that can only be filled by something, regardless of its specific content, labeled "Islamic." (Starrett, 1998:229)

The public role for Islam creates an opportunity for movements to situate their claims in the already accepted narrative of religion as a social tool. For example, religious movements in Egypt have positioned Islam as a solution to the problem of government corruption. After elections in professional associations, one engineer explained his vote: "I chose the Islamic Trend because they are honest and interested in reforming the country. By contrast, the leftists are interested in only obtaining position and material benefits for themselves" (quoted in Wickham, 2002:198). In short, religion is seen as a practical and legitimate answer to social problems. Islamic political organizations are more likely to thrive in an 
environment where a regime has already promoted religion as part of the government's response to social and political issues. Thus, the potential population of movement supporters and the resonance of religious claims are greater in societies that have a large public role for Islam.

State incorporation of Islam also increases access to mobilizing resources for movements with religious claims. Research in other contexts has found that religious institutions can be appropriated by political movements. For instance, church-based mobilization was important for the antiapartheid movement in South Africa (Borer, 1996) and the civil rights movement in the United States (McAdam, 1999; Morris 1984). In the Middle East, regimes that control religious function channel material resources into Islamic institutions, including state-run mosques, schools, and endowments. Islamic movements in Egypt built independent institutions parallel to those of the regime, but state-run religious institutions remain a primary site of recruitment (Wickham, 2002). For instance, indoctrination through religious schooling has been posited as one source of support for Islamic movements (Rashid, 2000). However, Andrabi et al. (2006) find that in Pakistan most religious education takes place in public schools rather than in independent madrasas. If religious education does create a mass base for mobilization, state schools are likely a primary source. By and large, Islamic organizations need not cultivate networks and resources from scratch; they can turn to the existing infrastructure created by a regime's assumption of religious function. State-run religious institutions are thus ready-made sites of political organization and mobilizing resources.

Finally, a state-maintained public role for Islam allows for movements that can weather political exclusion and repression. Hafez (2003) argues that exclusion and repression create Islamic militancy primarily through reaction to state actions. Political repression can certainly spark resentment and reaction (see, e.g., Rasler, 1996), but it can also successfully suppress opposition. However, regimes that create a public role for religion also create a site of mobilization that is relatively protected from state action. Quite simply, even the most dictatorial regime cannot completely shutter the mosque. In contrast, secular oppositions are often crushed by a regime or wither under its restrictions. This has even occurred in outright alliance with Islamic political movements. During the Egyptian Free Officers Coup in 1952, the new government initially sought support from the Muslim Brotherhood to suppress the communist opposition; a benefit for both the Muslim Brothers and the regime (Munson, 2001). Contentious politics in today's Middle East may center on Islam precisely because opponents to a regime have few other choices (Ajami, 1992; El-Ghobashy, 2005). Under a regime that circumscribes political 
participation and represses opposition, the legitimate frames and mobilizing resources created by a state's assumption of religious function are even more relevant. It is no surprise, then, that the most closed and repressive Middle Eastern states seem to have primarily Islamic oppositions.

In state incorporation of religion, then, lies a source of political Islam. By incorporating religion, the state legitimates Islamic frames as a form of political and social action, creates ready-made sites of mobilization through its support of religious institutions, and reduces secular alternatives through political exclusion and repression. The methods and degrees of incorporation of religion vary widely across the Middle East and, I argue, create the observed cross-national variation in the prevalence and tactics of Islamic organizations. With appropriate data on regimes' adoption of religion, political opportunities, and state repression, it is possible to empirically test a state-centered account of political Islam.

\section{DATA ON MIDDLE EASTERN POLITICAL ORGANIZATIONS AND STATES}

Data are collected on political and militant organizations primarily using the CIA World Factbook for 2002. This time point allows a consideration of the variation in political Islam before the potentially radicalizing influence of the 2003 U.S. invasion of Iraq, which is important for its effect but outside the scope of the explanations considered in this study. Political organizations are drawn from the political parties and political pressure groups data fields. In addition, militant organizations included in the data set are from the U.S. State Department's 2002 lists of designated and other terrorist organizations. When any organization operates in more than one nation, it is coded separately for each country. ${ }^{3}$ The data-collection scheme yields a list of 170 political and militant organizations for 19 Middle Eastern and North African countries. ${ }^{4}$ Table I presents the number of organizations by religiosity and militancy for each country in 2002 .

An organization is considered Islamic if it has at least two of the following: (1) an Islamic name, for example, reference to religious concepts, holy sites, or some version of the word "Islam"; (2) an Islamic clerical or spiritual leadership; or (3) significant Islamic issues in its platform beyond

3 The method of collection captures only organizations that are specifically named. Thus, it is not the full population of organizations in the region, which leads to some undercounts (e.g., the absence of political organizations in Lebanon; see Table I).

${ }^{4}$ The 19 countries are: Algeria, Bahrain, Egypt, Iran, Iraq, Jordan, Kuwait, Lebanon, Libya, Morocco, Oman, Qatar, Saudi Arabia, Sudan, Syria, Tunisia, Turkey, the United Arab Emirates, and Yemen. 
Table I. Number of Islamic and Non-Islamic Political and Militant Organizations by Country in the Middle East in $2002(N=170)$

\begin{tabular}{|c|c|c|c|c|c|}
\hline \multirow[b]{2}{*}{ Country } & \multicolumn{2}{|c|}{ Islamic } & \multicolumn{2}{|c|}{ Non-Islamic } & \multirow[b]{2}{*}{ Total $(N)$} \\
\hline & Political & Militant & Political & Militant & \\
\hline Algeria & 3 & 3 & 12 & - & 18 \\
\hline Bahrain & - & 1 & - & & 1 \\
\hline Egypt & 1 & 3 & 5 & - & 9 \\
\hline Iran & 7 & 4 & 6 & 3 & 20 \\
\hline Iraq & - & 2 & 1 & 5 & 8 \\
\hline Jordan & 3 & 2 & 13 & - & 18 \\
\hline Kuwait & - & 1 & - & - & 1 \\
\hline Lebanon & - & 6 & - & 3 & 9 \\
\hline Libya & - & 2 & - & - & 2 \\
\hline Morocco & 1 & 1 & 24 & - & 26 \\
\hline Oman & - & 1 & - & - & 1 \\
\hline Qatar & - & 1 & - & - & 1 \\
\hline Saudi Arabia & - & 1 & - & - & 1 \\
\hline Sudan & 4 & 1 & 1 & 1 & 7 \\
\hline Syria & 1 & 3 & 5 & 3 & 12 \\
\hline Tunisia & 1 & 1 & 6 & - & 8 \\
\hline Turkey & 2 & 2 & 12 & 2 & 18 \\
\hline UAE & - & 1 & - & - & 1 \\
\hline Yemen & 1 & 4 & 4 & - & 9 \\
\hline Total $(N)$ & 24 & 40 & 89 & 17 & 170 \\
\hline
\end{tabular}

common statements like "Shari'a as the basis of law" or "Islam as the religion of the country." When this information is not available, religiosity is determined by self-description, government description, or news source description (done through a review of major U.S. and world newspapers). This alternative coding is used only in a few cases. The dichotomous coding is limited by not accounting for the marked variation among Islamic organizations in how religious their claims are. However, it is nearly impossible to obtain clear statements of goals and purposes for every organization in the sample. Thus, I rely on the more crude dichotomous assessment of religiosity. It is also important to note that the organizations in the sample are primarily oppositional in nature, rather than religious partners to regimes. Thus, the sample does not merely represent state promotion of religious organizations.

I have argued that a regime's reliance on religious sources of legitimacy and an assumption of religious function are a primary origin of political Islam. Measuring this form of state building can be difficult since the methods of incorporation of religion vary widely. As a reasonable proxy I use Islamic education in state schools. Starrett (1998) argues that religious education in public schools is a key factor in the growth of 


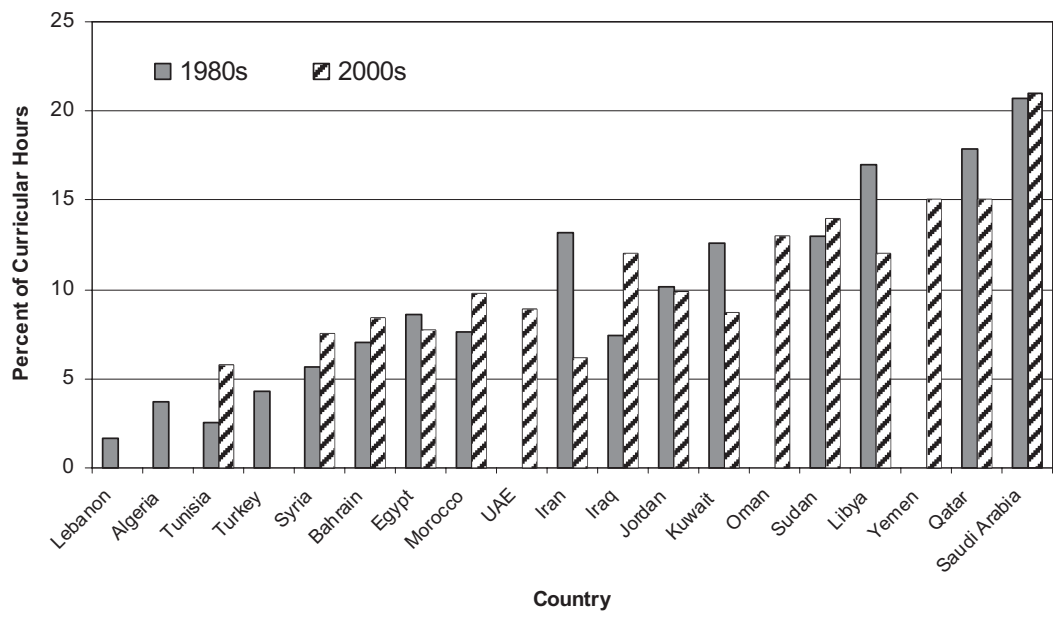

Fig. 1. Percent of instruction time in 1980s and 2000s devoted to Islamic education for all grades.

Note: Countries are presented in order of the average percent over both time points. There are no data available for Oman, United Arab Emirates, and Yemen in the 1980s, or for Algeria and Turkey in the 2000s. Lebanon has zero hours of religious education in the 2000s.

Islamic mobilization. As discussed previously, recent research on the prevalence of religious schooling in Pakistan finds that most instruction takes place in public schools (Andrabi et al., 2006), which is also likely the case for Middle Eastern countries. I construct the variable from the International Bureau of Education's 2003 summary of the percentage of hours of instructional time devoted to religious education. The percent hours is averaged across all grade levels. Figure 1 presents the average value for both time periods used (1980s and 2000s) by country. The results turn out largely as we might expect, ranging from countries like Turkey and Lebanon on the low end to Saudi Arabia as having the highest amount of Islamic education in public schools. Islamic education does not, however, appear to measure the religiousness of society at large. Bivariate correlation by country of religious education and the percentage of the population in the latest World Values Survey that felt religion was very important is not significant. Nor is the correlation between religious education and Pape's (2005) estimate of the Salafi influenced population significant. Islamic education in public schools is thus not the same as a society's religiosity, and can serve as a proxy for state incorporation of religion. It is also important to note that the indicator is time sensitive. Where there is substantial change between religious education in the 1980s and 2000s, it is mostly regression toward the mean. Thus, it appears that 


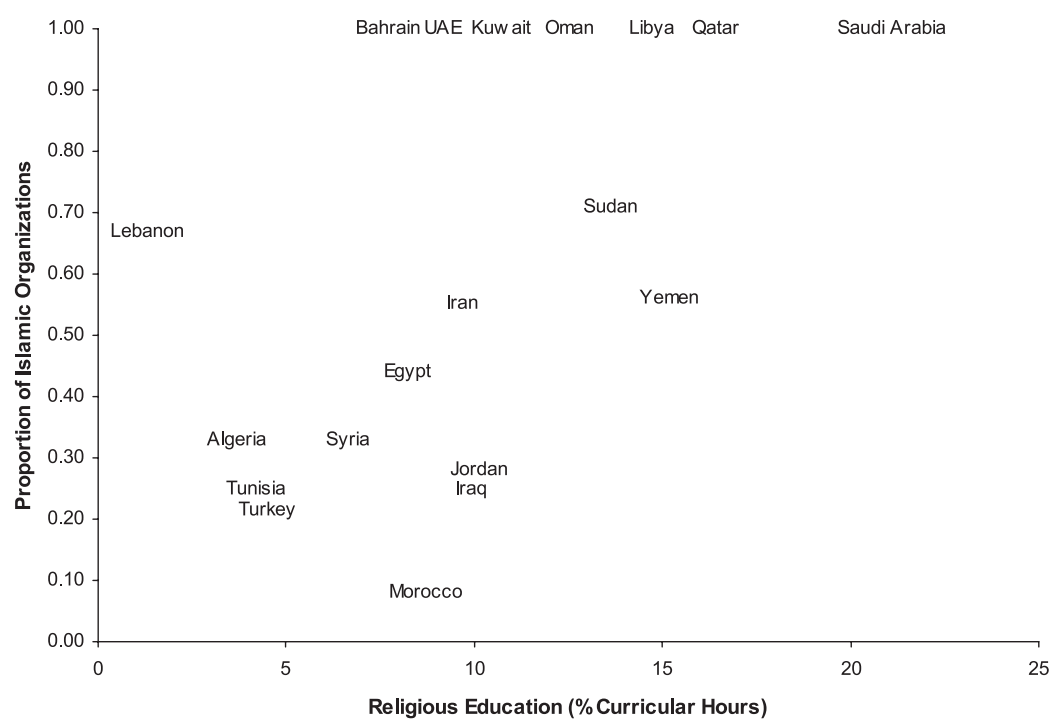

Fig. 2. Scatter plot of religious education by proportion of political and militant organizations that are Islamic.

Islamic education is not just the state's response to current religious movements. ${ }^{5}$

State incorporation of Islam as indicated by religious education does appear to correspond to the prevalence of Islamic organizations at the country level. Figure 2 presents a scatter plot of the proportion of all organizations that are Islamic by the percent of religious education. The variation is marked, but not surprising. On one extreme is Saudi Arabia, while on the other are more secular countries such as Turkey and Tunisia. As Islamic education grows, so does the tendency toward Islamic movements. There also appears to be a possible relationship to the geography of the Middle East. The countries of the Persian Gulf consistently appear at the high end of the spectrum, while Levantine and Maghreb countries tend to cluster toward the bottom. This, however, is primarily due to the lack of political organizations in the Gulf States (see Table I). In fact, dummy controls of region are not significant in any subsequent analysis conducted, and are thus excluded.

${ }^{5}$ A systematic time-series investigation could shed further light on this point. Regimes might adopt religion as a cooptive response to the threat of Islamic oppositions. If this were the case, state incorporation of religion would still have the effects I posit, acting as a positive feedback loop on preexisting Islamic mobilization. 
Previous research has also stressed the opportunities for political participation and state repression. I thus introduce two additional statecentered controls. First, I measure political exclusion using Freedom House's 2002 political rights score. This is a 1 to 7 scale that represents the political rights granted in a country. A higher score is more exclusion and less openness. On this scale, Turkey and Kuwait have the least exclusion with a score of 4, while Morocco and Jordan have a score of 5. Lebanon, Algeria, Tunisia, Bahrain, Egypt, the United Arab Emirates, Iran, Oman, Yemen, and Qatar have a score of 6. Syria, Iraq, Sudan, Libya, and Saudi Arabia have the most political exclusion with a score of 7 . Since the scale is constructed from an assessment of political rights like voting, the openness of elections, and so forth, it can be considered an indicator of political opportunities for participatory mobilization.

Second, following Hafner-Burton and Tsutsui (2005, 2007), I measure state repression through a scaled indicator of human rights abuse. HafnerBurton and Tsutsui synthesize measurements of state repression and political terror through a consideration of U.S. State Department and Amnesty International reports of human rights abuse. The resulting scale ranges from a score of 1 , countries with a firm rule of law and rare political imprisonment, torture, or murder, to 5 , countries with widely spread political terror. In 2002, only Oman rates a score of 1, while Bahrain, Kuwait, Morocco, and Qatar all have a score of 2. Iran, Jordan, Lebanon, Saudi Arabia, Libya, Syria, the United Arab Emirates, Yemen, Tunisia, and Turkey each rate 3. Finally, Algeria, Egypt, Iraq, and Sudan have the most repression with a score of 4 .

These three indicators, then, measure the relevant actions of Middle Eastern regimes - state incorporation of religion, the openness of the political system to participation, and state repression. I have argued that the origin of political Islam and its variation lies in the actions of states. It is now possible to examine this empirically.

\section{TESTING A STATE-CENTERED MODEL OF POLITICAL ISLAM}

For a systematic test of the proposed theory of state action as a source of Islamic political organization, I employ binary logistic regression where the dependent variable is whether or not an organization is Islamic. The primary independent variable is the indicator of state incorporation of religion - the average proportion of public education that is religious. I use two forms of these data: the raw percentage of hours of education that is religious; and a dichotomous coding constructed as high-low by taking the midpoint $(10.5 \%)$ between the lowest and highest amount of 
religious instructional time. The dichotomous indicator allows for an evaluation of high state incorporation of religion distinct from smaller gradations. Indicators of political exclusion - the Freedom House political rights score - and repression-Hafner-Burton and Tsutsui's human rights abuse scale - are used as they stand. ${ }^{6}$

Given their continued currency, I control for two other alternative explanations-foreign influence and economic grievances. There are two measurements of foreign influence. First, I use the proportion of imports from the United States drawn from the 2002 CIA World Factbook. This is one indicator of the strength of a country's connection to Western powers. Second, I compile the number of U.S. military personnel stationed in the country from the Defense Department's personnel deployment list from December 31, 2000. For most countries in peacetime, U.S. military personnel operate in either an advisory role or protect U.S. government installations. Thus, higher numbers of U.S. military personnel can also indicate a larger U.S. diplomatic presence. In the analyses conducted, I use a dichotomous indicator of nations that host more than 1,000 U.S. military personnel. The best measurement of economic grievances would be the Gini index or poverty rate. These figures, however, are unavailable or unreliable for a large number of Middle Eastern and North African countries. Instead, as controls for economic grievances, I use unemployment rate and gross domestic product per capita in 2002 (in constant U.S. dollars) from the CIA World Factbook and World Development Indicators database maintained by the World Bank.

Finally, I introduce demographic control variables. It is possible that some of the variation in Islamic political organization could be accounted for by differences between branches of Islamic theology. I thus include a dummy coding of whether or not the country has a Sunni religious majority. Next, I include whether or not the country is a member of Oil Producing and Exporting Countries (OPEC) in 2002. Oil wealth is certainly an important control, and it could also be considered as part of foreign influence or economic grievances. Finally, I control for population size in $2002 .^{7}$

${ }^{6}$ Following Hafner-Burton and Tsutsui (2007), I also examined the effect of a dichotomous coding of high repressor states (countries with a score of 3,4 , or 5). This dummy indicator bore no difference from the scale itself. I thus maintain the more varied human rights abuse scale in all analyses.

7 I also examined the possible role of civil war in generating political Islam, using a dichotomous code for civil war and the number of state casualties in civil war since 1991 drawn from the Correlates of War data set. Neither measure of civil war, however, was significant in any model estimated. As civil war is highly multicollinear with the state repression indicator, I exclude it from the final analyses presented. 
The results of binary logistic regression on the religiosity of organizations indicate strong support for a state-centered account of political Islam (see Table II). First and foremost, religious education in state-run schools significantly predicts organizational religiosity. The odds of a political organization being Islamic are greater by a factor of 1.36 for every $1 \%$ increase in religious education. The dichotomous coding of high rates of Islamic education also has the largest significant effect of any factor analyzed. The introduction of the latter indicator notably increases the goodness of fit (Model 5 compared to Model 3, Table II). This is a compelling result. As I have argued, Islamic political organizations are most probable when the state creates a place in the public sphere for religion.

The results also indicate that other accounts of the origins of political Islam do not have as much cross-national predictive value. Control variables of OPEC membership, Sunni majority, and population size do not have a consistent or significant effect. By itself, oil production may

Table II. Estimated Coefficients (Standard Errors) from Binary Logistic Regression of Religiosity of Middle Eastern Political and Militant Organizations $(N=170)$

\begin{tabular}{|c|c|c|c|c|c|}
\hline & Model 1 & Model 2 & Model 3 & Model 4 & Model 5 \\
\hline \multicolumn{6}{|l|}{ Controls } \\
\hline $\begin{array}{l}\text { OPEC member } \\
\text { state }\end{array}$ & $1.77 *(.74)$ & $.97(.76)$ & $1.14(.87)$ & $-1.50(1.33)$ & $2.09(2.79)$ \\
\hline Sunni majority & $.05(.69)$ & $-.28(.65)$ & $-.23(.68)$ & $-1.95(-.17)$ & $.06(1.72)$ \\
\hline Population (Ln) & $-.66 * *(.25)$ & $-.50 *(.24)$ & $-.49(.25)$ & $-.17(.26)$ & $-.74(.77)$ \\
\hline \multicolumn{6}{|c|}{ Foreign Influence and Economic Grievances } \\
\hline $\begin{array}{l}\text { 1,000+ U.S. } \\
\text { military }\end{array}$ & $.33(.71)$ & $1.25(.92)$ & $1.47(1.03)$ & $3.80 *(1.83)$ & $1.46(1.62)$ \\
\hline $\begin{array}{l}\text { U.S. imports } \\
(\%)\end{array}$ & $.05(.04)$ & $.06(.04)$ & $.08(.05)$ & $.11(.06)$ & $.19(.12)$ \\
\hline $\begin{array}{l}\text { Unemployment } \\
(\%)\end{array}$ & $-.09 *(.04)$ & $-.05(.04)$ & $-.05(.05)$ & $.10(.08)$ & $-.10(.12)$ \\
\hline $\begin{array}{l}\text { GDP per capita } \\
(\log )\end{array}$ & $-2.02 *(.96)$ & $-.89(1.10)$ & $-1.02(1.14)$ & $4.66(2.84)$ & $4.08 *(1.87)$ \\
\hline \multicolumn{6}{|l|}{ Political Opportunities } \\
\hline $\begin{array}{l}\text { Political rights } \\
\text { score }\end{array}$ & - & $.62(.33)$ & $.73(.40)$ & $1.60 *(.70)$ & $1.07(.68)$ \\
\hline \multicolumn{6}{|l|}{ Repression } \\
\hline $\begin{array}{l}\text { Human rights } \\
\text { abuse score }\end{array}$ & - & - & $-.24(.59)$ & $.18(.50)$ & $-.92(1.13)$ \\
\hline \multicolumn{6}{|c|}{ State Incorporation of Islam } \\
\hline $\begin{array}{l}\text { Religious } \\
\text { education (\%) }\end{array}$ & - & - & - & $.31 *(.14)$ & - \\
\hline $\begin{array}{l}\text { High religious } \\
\text { education }\end{array}$ & - & - & - & - & $5.22 * *(1.92)$ \\
\hline Constant & $14.26^{* *}(5.35)$ & $4.49(6.95)$ & $4.81(7.20)$ & $-28.84(17.03)$ & $-11.59(11.57)$ \\
\hline Model chi-square & $18.75^{*}$ & $22.28^{* *}$ & $22.58 * *$ & $29.51 * * *$ & $41.55^{* * *}$ \\
\hline
\end{tabular}


increase the likelihood of Islamic organization and larger populations reduce it, but neither factor matters once regime actions of religious incorporation and state repression are taken into account. The results also show no consistent effect for economic grievances, measured by unemployment and GDP per capita. This result is expected and replicates the results of previous research (see Krueger and Maleckova, 2003). Finally, the lack of a consistent or significant effect of the variables of U.S. military presence and imports provides little support for accounts of political Islam as solely a reaction to foreign influence.

The overall picture of state action, however, is not as straightforward. First, state repression does not seem to matter for the likelihood of Islamic organizations. There is no significant effect of the repression indicator, the human rights abuse score, in any model estimated. This is an unexpected result and indicates that both Islamic and secular mobilization respond similarly to a repressive environment. Second, the indicator of opportunities for participation, the political rights score, does not consistently have a significant effect on the likelihood of an organization being Islamic. It is noteworthy that the effect does trend in a positive direction across all models estimated, and approaches stronger significance once all state-centered variables are included (Model 4 and 5, Table II). These results have two implications: first, political exclusion and opportunities for participation matter only once state incorporation of religion is taken into account; and second, repression and exclusion are not by themselves universal origins of political Islam. If the establishment of Islamic political organizations came primarily as a result of political liberalization or a reaction to repression, then the effects of these two variables should be the exact opposite of what they are.

Of the two imageries of state-centered theory, I have argued that the inadvertent creation of religion as a legitimate mobilizing frame is a more fitting account than political Islam as a reaction to state control of religion. It is possible to shed some light on which mechanism may best explain variation cross-nationally. If state incorporation of religion inspires reaction, it is reasonable to expect that it would come partially in militant forms. Reactive movements are more likely to be opposed to the very existence of the regime and seek to overthrow it, rather than participate in its political routines. Thus, the effects of the religious education indicator should be stronger for the subset of organizations that are both militant and Islamic. To examine this, I conduct another set of analyses using binary logistic regression where the dependent variable is a dichotomous coding of whether or not an organization is both militant and Islamic. All models estimated are the same as those presented in Table II. Crucially, Islamic education has no significant effects on Islamic militancy 
in these models. The nonsignificant coefficients of the percent of religious education and the dichotomous coding of high religious education are only half as strong as the previous analysis of all Islamic organizations. This difference is noteworthy as the majority of religious organizations in the sample analyzed are militant (see Table I). It is thus highly indicative that incorporation of religion by the state does matter, but does not only create reactive Islamic militancy. I take this as evidence that the imagery of a state legitimation of Islamic political action is more fitting than that of a popular reaction to a regime's infringement on religious practice. ${ }^{8}$

The results of the analyses also speak to an additional mechanism by which state incorporation of religion generates Islamic movements. I proposed that religious organizations may better withstand repression and political exclusion. The evidence on this point is mixed. State repression does not seem to affect the likelihood of Islamic organizations. There may, however, be a role for a system closed to political participation. As I have argued, political exclusion makes Islamic movements more likely only in the context of a legitimate public role for religion. Without that process, there appears to be little difference between religious and secular movements.

Overall, the models estimated indicate support for the thesis that state reliance on religious imagery and assumption of religious function, as indicated by religious education in public schools, is a primary origin of political Islam and its cross-national variation. Analysis suggests that this occurs through mechanisms of legitimating frames and the ability of religious organizations to withstand political exclusion, rather than reaction to state control of religion. The lack of consistent support for economic and foreign influence factors shows that a state-centered explanation of political Islam is perhaps the most fitting account.

\section{CONCLUSIONS}

I have argued that state-building efforts vis-à-vis religion are a primary source of the variation in Islamic political organization in today's

\footnotetext{
${ }^{8}$ The overall contours of this analysis also have interesting implications for further research. Negative effects of population size are stronger and the amount of U.S. imports has a consistent significant and positive effect on Islamic militancy. Foreign influence may thus matter more for militant than for participatory movements. Repression, as measured by human rights abuse, still does not have significant effects on the likelihood of Islamic militant organizations at all. However, decreasing political rights do have a significant positive effect on the likelihood of Islamic militancy across all models. As discussed previously, a lack of opportunities for participation may create militancy. Full results are available from the author on request.
} 
Middle East. Regimes seek to legitimate their rule and coopt traditional religious establishments by incorporating religious symbolism and functions. Islam's role in the public sphere then legitimates religion as a form of political action. I proposed that state incorporation of religion also creates sites of mobilization for Islamic movements and protects them from repression and political exclusion. With the data available, I am unable to directly test the first mechanism, and I find mixed support for the latter. However, the results of analyses conducted do support state incorporation of religion as a source of political Islam. It seems that this occurs primarily through the unintentional creation of legitimating frames for mobilization. In sum, a state-centered approach to political Islam can explicitly account for the variation in religious political and militant organizations across the Middle East.

There are, however, some methodological limitations to the conclusions that can be drawn from this study. First, as noted previously, the dichotomous coding of an organization's religiosity is one-dimensional. Islamic movements vary widely in the extent of their religious claims and goals, and the analysis is unable to empirically account for this. I believe it is likely that state action also accounts for variation in religiosity across Islamic movements, but without further investigation cannot say so conclusively. Second, the data gathered are only a snapshot in time of what is a much longer historical process. Religion and regime in the Middle East and North Africa have interacted over decades, if not even longer, to create the current political environment. It is plausible that states take on religious function as a reaction to Islamic mobilization, just as Islamic movements respond to state building. Future research should take this interplay seriously and continue to consider how Islamic societies and states have evolved side by side.

State building is also only one part of a complex story. This study has looked for universal, cross-national effects from previous accounts of political Islam. Even when consistent effects have not been found, as in the case of political opportunities and repression, this does not mean these factors do not matter at all. As previous case studies have demonstrated, movement processes, political opportunities, reaction to repression, and foreign influence can help generate Islamic mobilization. Furthermore, I make no claim that state action alone is the primary cause of the intensity or popularity of Islamic activism. This, I believe, is better explained by a focus on the internal processes and strategies of Islamic political organizations, which is the realm of social movement theory. I have argued that movement processes, such as access to mobilizing structures and responses to exclusion and repression, are structured by the environment a regime constructs. Yet more research from a social 
movement perspective will help us understand the dynamics and, perhaps, future trajectory of religious mobilization. Grievances, be they cultural, economic, or political, likely also play a necessary if insufficient role in sparking Islamic activism. Continued consideration of symbolic and ideational processes also will help make sense of the complex and varied uses of religion in politics. In examining cross-national variation, this study seeks to illuminate which factors should be candidates for further theoretical and empirical consideration. I selected the possible sources of political Islam primarily from case studies, and I hope that future case studies will incorporate the factors for which I have found support.

\section{REFERENCES}

Aburish, Said. 1997. A Brutal Friendship: The West and the Arab Elite. London: Indigo.

Ajami, Fouad. 1992. The Arab Predicament: Arab Political Thought and Practice Since 1967. Cambridge, UK: Cambridge University Press.

Andersen, Benedict. 1991. Imagined Communities. London: Verso.

Andrabi, Tahir, Jishnu Das, Asim Ijaz Khwaja, and Tristan Zajonc. 2006. "Religious School Enrollment in Pakistan: A Look at the Data," Comparative Education Review 50: 3: 446477.

Arjomand, Said A. 1988. The Turban for the Crown: The Islamic Revolution in Iran. New York: Oxford University Press.

Arjomand, Said A. 2001. "Perso-Indian Statecraft, Greek Political Science and the Muslim Idea of Government," International Sociology 16: 3: 455-473.

Ayoob, Mohammed. 2005. "The Future of Political Islam: The Importance of External Variables," International Affairs 81: 5: 951-961.

Barth, Frederick. 2000. "Are Islamists Nationalists or Internationalists?" In Kjell Goldmann, Ulf Hannerz, and Charles Westin (eds.), Nationalism and Internationalism in the Post-Cold War Era: pp. 51-64. New York: Routledge Press.

Bendle, Mervyn F. 2003. "Militant Religion and the Crisis of Modernity: A New Paradigm," Research in the Social Scientific Study of Religion 14: 229-252.

Bergesen, Albert. 2008. "Islam and Democracy: A Response to Amitai Etzioni," Sociological Forum 23: 1: 183-184.

Borer, Tristen A. 1996. "Church Leadership, State Repression, and the 'Spiral of Involvement' in the South African Anti-Apartheid Movement, 1983-1990," In Christian Smith (ed.), Disruptive Religion: The Force of Faith in Social-Movement Activism: pp. 125-146. New York: Routledge.

Casanova, Jose. 1994. Public Religions in the Modern World. Chicago, IL: University of Chicago Press.

Chomsky, Noam. 1983. The Fateful Triangle: The United States, Israel and the Palestinians. Boston, MA: South End Press.

Chomsky, Noam. 2002. 9-11. New York: Seven Stories Press.

Clark, Janine A. 2004. Islam, Charity, and Activism: Middle-Class Networks and Social Welfare in Egypt, Jordan, and Yemen. Bloomington, IN: Indiana University Press.

Eisenstadt, S. N. 1999. Fundamentalism, Sectarianism and Revolution: The Jacobin Dimension of Modernity. Cambridge, UK: Cambridge University Press.

Eisenstadt, S. N. 2002. "Concluding Remarks: Public Sphere, Civil Society, and Political Dynamics in Islamic Societies," In Miriam Hoexter, S. N. Eisenstadt, and Nehemia Levtzion (eds.), The Public Sphere in Muslim Societies: pp. 139-162. Albany, NY: State University of New York Press. 
El-Ghobashy, Mona. 2005. "The Metamorphosis of the Egyptian Muslim Brothers," International Journal of Middle Eastern Studies 37: 3: 373-395.

Etzioni, Amiati. 2008. "Will the Right Islam Stand Up?" Sociological Forum 23: 1: 174-182.

Gautier, Mary L. 1998. "Church Elites and the Restoration of Civil Society in the Communist Societies of Central Europe," Journal of Church \& State 40: 2: 289-317.

Hafez, Mohammed M. 2003. Why Muslims Rebel: Repression and Resistance in the Islamic World. Boulder, CO: Lynne Rienner Publishers.

Hafner-Burton, Emilie M., and Kiyoteru Tsutsui. 2005. "Human Rights in a Globalizing World: The Paradox of Empty Promises," American Journal of Sociology 110: 5: 13731411 .

Hafner-Burton, Emilie M., and Kiyoteru Tsutsui. 2007. "Justice Lost! The Failure of International Human Rights Law to Matter Where Needed Most," Journal of Peace Research 44: 4: 407-425.

Huntington, Samuel. 1996. The Clash of Civilizations and the Remaking of the World Order. New York: Simon and Schuster.

Krueger, Alan B., and Jitka Maleckova. 2003. "Education, Poverty, and Terrorism: Is There a Causal Connection?" Journal of Economic Perspectives 17: 4: 119-144.

Kurzman, Charles. 1996. "Structural Opportunity and Perceived Opportunity in SocialMovement Theory: The Iranian Revolution of 1979," American Sociological Review 61: 1: $153-170$.

Mann, Michael. 1986. Sources of Social Power: Volume 1, A History of Power from the Beginning to $A D$ 1760. Cambridge, UK: Cambridge University Press.

McAdam, Doug. 1999."Introduction to the Second Edition," In Political Process and the Development of Black Insurgency, 1930-1970, 2nd ed.: pp. vii-xlii. Chicago, IL: University of Chicago Press.

Meyer, David S. 2004. "Protest and Political Opportunities," Annual Review of Sociology 30: $125-145$.

Moaddel, Mansoor. 2002a. Jordanian Exceptionalism: A Comparative Analysis of StateReligion Relationships in Egypt, Iran, Jordan, and Syria. New York: Palgrave MacMillan.

Moaddel, Mansoor. 2002b. "The Study of Islamic Culture and Politics: An Overview and Assessment," Annual Review of Sociology 28: 359-386.

Morris, Aldon D. 1984. The Origins of the Civil Rights Movement: Black Communities Organizing for Change. New York: Free Press.

Munson, Ziad. 2001. "Islamic Mobilization: Social Movement Theory and the Egyptian Muslim Brotherhood," Sociological Inquiry 42: 4: 487-510.

Nasr, Seyyed Vali Reza. 2001. Islamic Leviathan: Islam and the Making of State Power. New York: Oxford University Press.

Norris, Pippa, and Ronald Inglehart. 2002. "Islamic Culture and Democracy: Testing the 'Clash of Civilizations' Thesis," Comparative Sociology 1: 3/4: 235.

Pape, Robert. 2003. "The Strategic Logic of Suicide Terrorism," American Political Science Review 97: 3: 343-361.

Pape, Robert. 2005. Dying to Win: The Strategic Logic of Suicide Terrorism. New York: Random House.

Rashid, Ahmed. 2000. Taliban: Militant Islam, Oil, and Fundamentalism in Central Asia. New Haven, CT: Yale University Press.

Rasler, Karen. 1996. "Concessions, Repression, and Political Protest in the Iranian Revolution," American Sociological Review 61: 1: 132-152.

Rokkan, Stein. 1975. "Dimensions of State Formation and Nation-Building: A Possible Paradigm for Research on Variations within Europe," In Charles Tilly (ed.), The Formation of National States in Western Europe: pp. 562-600. Princeton, NJ: Princeton University Press.

Said, Edward. 1978. Orientalism. New York: Random House.

Schwedler, Jillian. 2006. Faith in Moderation: Islamist Parties in Jordan and Yemen. Cambridge, UK: Cambridge University Press.

Sharabi, Hisham B. 1963. "Power and Leadership in the Arab World," Orbis 7: 3: 583-595. 
Snow, David A., and Scott C. Byrd. 2007. "Ideology, Framing Processes, and Islamic Terrorist Movements," Mobilization 12: 2: 119-136.

Snow, David A., and Susan Marshall. 1984. "Cultural Imperialism, Social Movement, and the Islamic Revival," Research in Social Movements, Conflicts, and Change 7: 131-152.

Snow, David A., E. Burke Rochford, Jr., Steven K. Worden, and Robert D. Benford. 1986. "Frame Alignment Processes, Micromobilization, and Movement Participation," American Sociological Review 51: 4: 464-481.

Starrett, Gregory. 1998. Putting Islam to Work: Education, Politics, and Religious Transformation in Egypt. Berkeley, CA: University of California Press.

Sutton, Phillip, and Stephen Vertigans. 2006. "Islamic 'New Social Movements"? Radical Islam, Al-Qa'ida and Social Movement Theory," Mobilization 11: 1: 101-115.

Swanson, Guy. 1967. Religion and Regime: A Sociological Account of the Reformation. Ann Arbor, MI: University of Michigan Press.

U.N. Development Program. 2002. Arab Human Development Report 2002. New York: United Nations Publications.

Wickham, Carrie Rosefsky. 2002. Mobilizing Islam: Religion, Activism, and Political Change in Egypt. New York: Columbia University Press.

Wiktorowicz, Quintan. 2000. "Civil Society as Social Control: State Power in Jordan," Comparative Politics 33: 1: 43-61.

Wiktorowicz, Quntan (ed.). 2004. Islamic Activism: A Social Movement Theory Approach. Bloomington, IN: Indiana University Press. 